\title{
SURGICAL CARE ARRANGEMENT AT THE GENERAL HOSPITAL DURING THE COVID-19 PANDEMIC
}

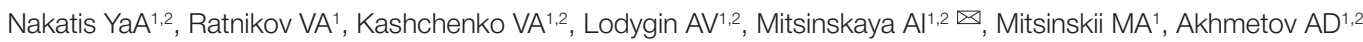

${ }^{1}$ L.G. Sokolov Memorial Hospital № 122, Saint-Petersburg, Russia

${ }^{2}$ St Petersburg University, Saint-Petersburg, Russia

The spread of caused by SARS-CoV2 acute respiratory infection associated with severe life-threatening complications has necessitated transformation of most general hospitals into infectious diseases hospitals in order to provide specialized care to infected patients, as well as the change of surgical care provision strategy. The example of surgical service reorganization has been reported for the general clinic transformed into the infectious diseases hospital capable of providing care both during the COVID-19 pandemic and after the outbreak has abated.

Keywords: COVID-19, SARS-CoV2, pandemic, coronavirus, surgery, surgical procedure

Author contribution: Nakatis YaA, Ratnikov VA, Kashchenko VA — study concept and design; Mitsinskaya Al, Mitsinskii MA, Akhmetov AD — data acquisition and processing; Lodygin AV, Mitsinskaya Al, Mitsinskii MA — manuscript writing; Kashchenko VA, Lodygin AV — manuscript editing.

Compliance with ethical standards: the patient submitted informed consent to treatment.

$\triangle$ Correspondence should be addressed: Alexandra I. Mitsinskaya

Leninsky prospect 127/4, k. 48, Saint-Petersburg, 198216; sashaart2012@yandex.ru

Received: 18.10.2020 Accepted: 11.11.2020 Published online: 28.11.2020

DOI: $10.47183 /$ mes.2020.015

\section{ОРГАНИЗАЦИЯ ХИРУРГИЧЕСКОЙ ПОМОЩИ В МНОГОПРОФИЛЬНОМ СТАЦИОНАРЕ В УСЛОВИЯХ ПАНДЕМИИ COVID-19}

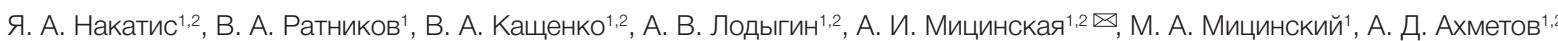 \\ К Клиническая больница № 122 имени Л. Г. Соколова Федерального медико-биологического агентства России, Санкт-Петербург, Россия \\ ${ }^{2}$ Санкт-Петербургский государственный университет, Санкт-Петербург, Россия
}

\begin{abstract}
Повсеместное распространение острого респираторного заболевания, вызванного вирусом SARS-CoV2 и сопровождающегося развитием тяжелых, угрожающих жизни осложнений, привело к необходимости перепрофилирования большинства многопрофильных стационаров с целью обеспечения специализированной помощи инфекционным больным, а также потребовало изменения стратегии оказания хирургической помощи. Представлен пример реорганизации хирургической службы в исходно многопрофильной клинике, перепрофилированной в инфекционный стационар, способный оказывать помощь пациентам как в условиях пандемии COVID-19, так и после ее окончания.

Ключевые слова: COVID-19, SARS-CoV2, пандемия, коронавирус, хирургия, оперативное вмешательство

Вклад авторов: Я. А. Накатис, В. А. Ратников, В.А. Кащенко - концепция и дизайн исследования; А. И. Мицинская, М. А. Мицинский, А. Д. Ахметов - сбор и обработка материала; А. В. Лодыгин, А. И. Мицинская, М. А. Мицинский - написание текста; В. А. Кащенко, А. В. Лодыгин - редактирование статьи. Соблюдение этических стандартов: пациентка подписала добровольное информированное согласие на лечение.
\end{abstract}

$\bowtie$ Для корреспонденции: Александра Игоревна Мицинская

Ленинский проспект, д. 127/4, к. 48, г. Санкт-Петербург, 198216; sashaart2012@yandex.ru

Статья получена: 18.10.2020 Статья принята к печати: 11.11.2020 Опубликована онлайн: 28.11.2020

DOI: $10.47183 /$ mes.2020.015

The COVID-19 (CoronaVirus Disease 2019) pandemic has been considered the largest outbreak of atypical viral pneumonia since 2002. In 2002 there was a similar, but less extensive, outbreak of SARS-CoV causing the severe acute respiratory syndrome (SARS) [1].

The World Health Organization $(\mathrm{WHO}$ ) recognized the global spread of COVID-19 on March 11, 2020 [1]. The widespread ubiquitous infection with novel virus, lack of acquired immunity in the population, susceptibility among all age groups, as well as severe life-threatening complications made it necessary to introduce the measures to minimize the infection spread. These were self-isolation and quarantine together with transformation of most general hospitals into the infectious disease hospitals in order to provide specialized care to infected people [2]. The medical institutions modernization process went through a number of approbations of various tactics and schemes for transformation of non-infectious clinics into the infectious diseases hospitals.

The issue worth special attention is the arrangement of surgical care during the pandemic, since the high risk of viral contamination to operating team during surgical treatment of patients with COVID-19 without appropriate protection has been reported $[3,4]$. It has now become evident that surgery during the pandemic requires taking into account a number of specific factors affecting surgical procedures both in patients with coronavirus infection and conditionally "clean" patients.

The general pandemic-related principles of surgical care arrangement are as follows. The surgical care of patients in the hospital should be limited to those whose needs are imminently life threatening. All elective surgical procedures should be postponed, and surgical priorities should be shifted to emergency care. The protocols of non-surgical management are currently being developed for patients whose surgical treatment may be postponed.

Transformation of the clinic into the infectious disease hospital for patients with COVID-19 results in certain matters impeding the work of surgical service. These include surgical beds elimination, surgical specialists' redeployment, operating rooms used as intensive care units. The described issues may result in longer interval between diagnosis and surgery, reduced quality of surgical care and increased rates of complications [3]. Furthermore, the high risk of staff contamination during surgery calls for total revision of surgical care arrangement principles. 
The key principle of safe and effective management includes constructing the clear hospital plan dividing the entire hospital area into "red" and "green" zones connected via single transition zone [2]. Operating room and intensive care unit should be located in the "red" zone.

Effective work is ensured by schedule optimization and mandatory presence of experienced surgeon in the on-duty surgical team. The surgeon should have time for consultations and surgical interventions.

To ensure safety and efficiency of surgical service during the pandemic the technical aspects of surgical intervention should be revised. Thus, surgery should be reduced to the minimum possible for current clinical situation extent. This will make it possible to reduce the duration of operation and to avoid the patient's admission to the intensive care unit overloaded with severe COVID-19 patients. Moreover, electrocoagulation generates aerosol with high concentration of viral particles, which increases the risk of the operation room staff contamination. Consequently, the energy of electrocoagulation should be minimized. When technically possible, the use of electrocoagulation should be avoided.

The use of ultrasonic dissectors, monopolar electrosurgery and advanced bipolar devices should be minimized, since these can lead to the infected aerosol formation. It is better to use monopolar diathermy devices with attached smoke evacuators.

Laparoscopy requiring an artificial pneumoperitoneum is also an aerosol-generating procedure. The smoke leaking from abdominal cavity and produced by laparoscopic electrocoagulators has high concentration of viral particles, which necessitates the use of intelligent continuous-flow systems making it possible to maintain minimal intra-abdominal pressure and facilitating the smoke evacuation into a closed circuit [4].

Attention should be paid to the incisions length and port insertion method in order to prevent $\mathrm{CO}_{2}$ leakage from abdominal cavity. Sudden removal of trocars should be avoided, and active aspiration should be used after the procedure. All $\mathrm{CO}_{2}$ should be safely evacuated via a filtration system before closure [4]. Despite the proposed methods of laparoscopy techniques optimization in COVID-19 patients, it has been suggested that open surgery has some advantages in terms of operating room staff safety $[5,6]$. There is no consensus on the presence of novel coronavirus in the peritoneum, but the presence of virus in the intestinal lumen and in the urinary tract is beyond doubt. This defines recommendations to consider the luminal opening or urinary drainage and bladder catheterization as additional risk factors for staff contamination. Thus, it is extremely important to prevent the infected aerosol formation and to minimize the operating room staff exposure to biological fluids.

The $\mathrm{WHO}$ issued a number of recommendations for surgical team management during the COVID-19 pandemic [4, 7]. The compliance with the recommendations for anesthesia is also important [8].

1. All manipulations to prepare the patient for anesthesia (central vein cannulation, endotracheal intubation) should be performed in the intensive care unit. After that the patient should be transferred to the operation room using the transport ventilator.

2. Sedative medications that may cause airway obstruction or hypoventilation requiring urgent intubation should be avoided.

3. The use of laryngeal masks, deep sedation and fiberoptic intubation in conscious patients should be limited.

4. If possible, regional anesthesia and the use of low-flow nasal cannula delivery systems should be preferred.

5. When performing surgery in COVID-19 patients, it is recommended to use low tidal volume ventilation with permissive hypercapnia and high positive end-expiratory pressure. In patients with refractory hypoxemia/hypercapnia or increased airway pressure, the use of prolonged neuromuscular blockade should be considered. The target $\mathrm{SpO}_{2}$ (hemoglobin oxygen saturation) level is $88-92 \%$.

During intubation and extubation of patients with novel coronavirus infection the following algorithm should be used [8].

1. The anesthesiology team which performs intubation should include two anesthesiologists or one anesthesiologist and the staff nurse wearing two pairs of gloves.

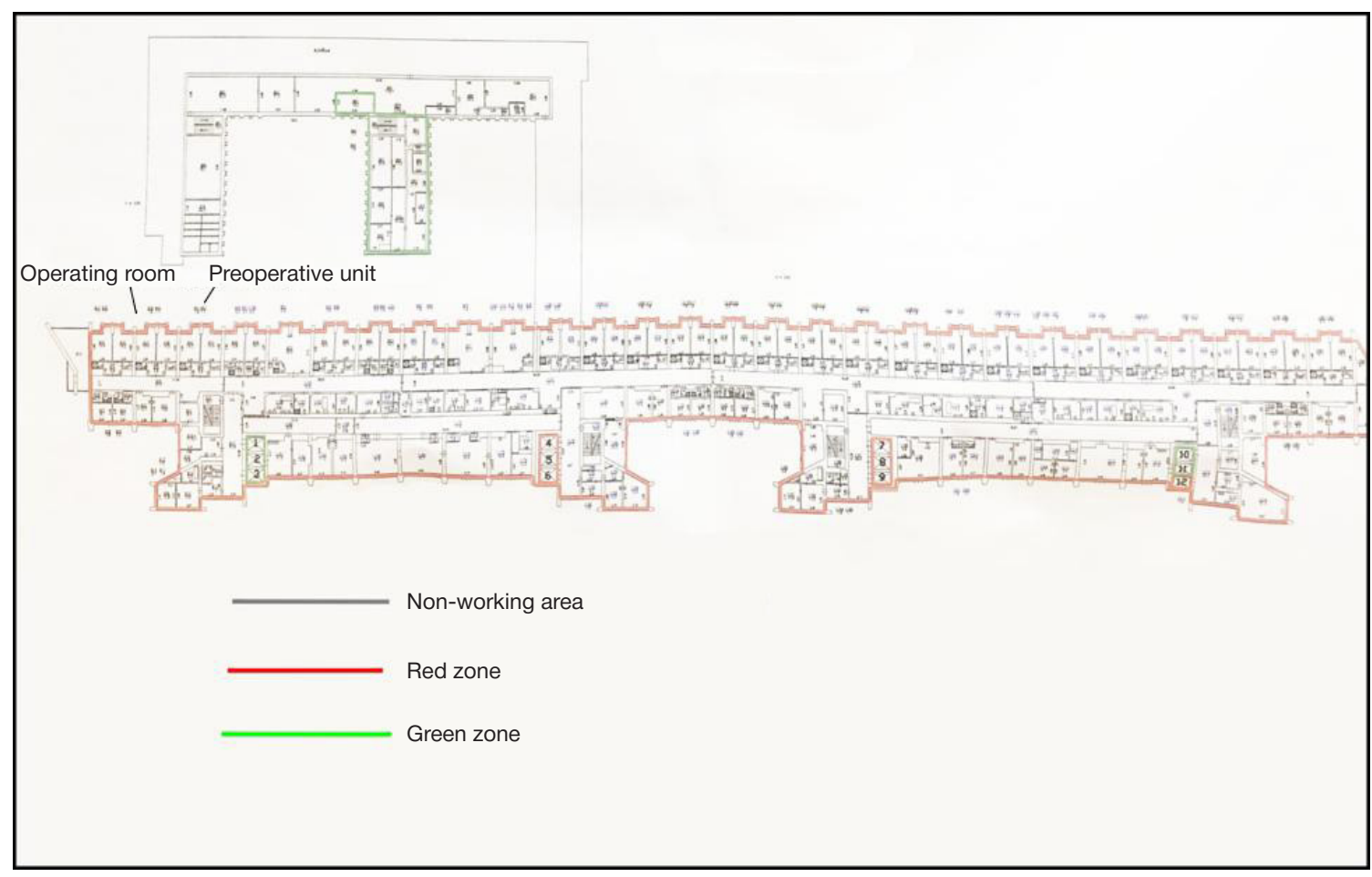

Fig. 1. Layout of operating room located in the red zone 


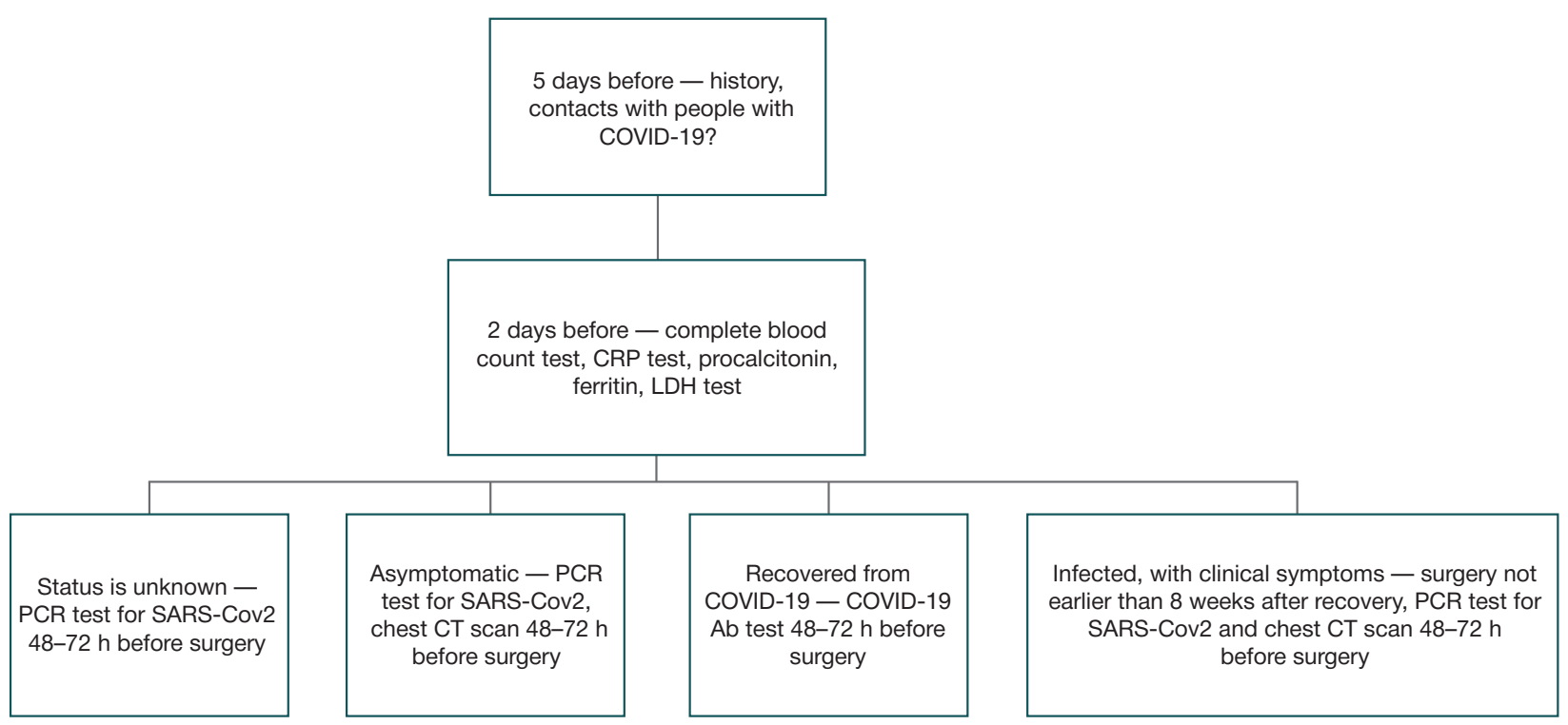

Fig. 2. COVID-19 screening pathway for patients in need for elective surgery. CRP - C-reactive protein; LDH — lactate dehydrogenase; PCR - polymerase chain reaction; chest CT — chest computed tomography; Ab — antybody

2. Extubation should be considered only in patients meeting criteria for extubation with no indications for intensive care unit stay.

3. During extubation only anesthesiologists and appropriate team members should stay in the operating room. The unnecessary staff should leave the operating room at the time of manipulation. They may enter the operation room again no earlier than 15 minutes after extubation completion.

4. The nurse wearing PPE should monitor the patient's awakening. Then the patient should be moved on the gurney and transferred to hospital ward using the surgical mask, gloves and protective disposable cap.

The patient's transfer to and out of the operating room should be as quick as possible. It should be performed away from other patients' accommodation. After that the thorough sanitization of all used facilities should be carried out.

Our aim was to report the surgical service arrangement at the L.G. Sokolov Memorial Hospital No. 122 transformed into the infectious disease hospital during the pandemic.

\section{Clinical case}

Prior to the COVID-19 pandemic a wide range of laparoscopic and open surgical procedures was performed at the L.G. Sokolov Memorial Hospital № 122. After transformation into the infectious diseases hospital all elective surgical cases were cancelled; only the life-saving surgical procedures were performed. The 350 hospital beds for infected patients were deployed. Fig. 1 provides the clinic floor plan showing the operating room suitable for emergency surgical patients with COVID-19.

The case of emergency surgery in patient with novel coronavirus infection and intra-peritoneal bleeding is reported.

The female patient $B$, aged 89 , with clinical signs of bilateral community-acquired pneumonia and suspected COVID-19 was admitted to the L.G. Sokolov Memorial Hospital No. 122 on May 30, 2020. The diagnosis of COVID-19 was later confirmed by PCR test. Based on the clinical picture, patient's history, examination results, laboratory and instrumental tests, the following diagnosis was established:

Primary diagnosis: coronavirus disease caused by SARSCoV-2, virus identified, severe course.

Complications: community-acquired bilateral polysegmental pneumonia (CT-3). III degree respiratory failure.
Secondary diagnosis: coronary artery disease. III class stable angina pectoris. Atherosclerotic cardiosclerosis. Grade 3 essential hypertension. Grade 3 hypertension. Very high risk of cardiovascular complications.

Due to severity of the disease, the patient was hospitalized in the cardiac intensive care unit. On June 1, 2020 the following hemodynamic changes were observed: blood pressure drop to $80 / 60 \mathrm{mmHg}$, tachycardia 140 beats per minute, and the need for sympathomimetic therapy. The complete blood count (CBC) test results showed the pronounced decline in hemoglobin level over time to $45 \mathrm{~g} / \mathrm{L}$ (severe anemia). Abdominal CT scan revealed signs of spleen rupture and hemoperitoneum (it was also known from the case history that the patient fell off in her apartment on May 29, 2020). The patient was in need of livesaving surgery.

After intubation, performed in the intensive care unit by the equipped with PPE anesthesiology team members, the patient was prepared for urgent surgery. The surgical team was provided with PPE and P100 (HEPA) full-face respiratory protection equipment. A sterile surgical gown and sterile latex gloves were worn over the PPE.

Laparotomy using the monopolar electrocoagulator with lowest possible power setting was performed. Abdominal cavity revision revealed $2000 \mathrm{~mL}$ of blood with clots. Vizualization of the spleen revealed a linear rupture near the upper splenic edge. Splenectomy, peritoneal debridement and drainage were carried out. After surgery the patient was transferred to the intensive care unit for further treatment without extibation. No surgical complications were detected during the postoperative period. During the next week, the underlying disease progression was noted. Despite the intensive conservative therapy, the patient died on the day 10 of hospital stay due to comorbidities and age factor, as well as to progressive respiratory failure.

The control nasopharyngeal swab samples tested by PCR were SARS-Cov2 negative in all team members. Monitoring of the operating room staff over the next 14 days also revealed no clinical signs of COVID-19.

\section{Discussion}

The clinical case reported proves the need to elaborate principles for the correct surgical care provision to patients 
with novel coronavirus infection. Consistency throughout the recommendations makes it possible to ensure safety of patient and staff during surgery. Moreover, the COVID-19 spread not only contributes to the need for surgical tactics correction during the pandemic, but also defines the further surgical service reorganization strategy after the outbreak has abated.

In case of epidemiological situation stabilization and incidence plateau it is necessary to gradually expand the range of surgical services provided. In case of no disease outbreaks and minimized person-to-person transmission the elective surgery may be resumed.

The activities should be resumed after screening of all healthcare workers for COVID-19. Next step is the institutional resources evaluation

The decision about elective surgery should be made based on the surgical care promptness, institutional resources availability (including the intensive care unit bed availability), disease severity, history of cancelled surgical procedures and the patient's demographic data. In order to minimize the spread of infection, all patients with suspected COVID-19 requiring surgical treatment should be considered positive until proven otherwise [9]. Pre-operative assessment should be performed in accordance with the following protocol [10] (Fig. 2).
Maximum reduction of rehabilitation period contributes to reduced hospital length of stay. Referrals to rehabilitation centers should be avoided; on day 12-14 after discharge another nasopharyngeal swab tested for SARS-Cov2 by PCR should be performed [11].

It is important to remember that prevention of nosocomial COVID-19 outbreaks requires respect for discipline at work, patient routing and strict adherence to principles of asepsis and antisepsis.

\section{CONCLUSION}

Current epidemiological situation that has developed due to the COVID-19 spread contributes to the change of surgical care provision strategy in the clinics transformed into infectious diseases hospitals, and makes it necessary to revise the surgical care principles after the pandemic has abated. The change affects both surgery in patients with coronavirus infection and surgical treatment in conditionally "clean" patients during a period of unfavorable epidemiological situation. Selective and standardized approach together with strict adherence to recommendations ensures high efficiency of surgical care provision and safety of healthcare specialists.

\section{References}

1. Profilaktika, diagnostika i lechenie novoj koronavirusnoj infekcii (SOVID-19). Vremennye metodicheskie rekomendacii. Versija 6 (28.04.2020). Dostupno po ssylke: https://static-1. rosminzdrav.ru/system/attachments/attaches/000/050/116/ original/28042020_\%D0\%9CR_COVID-19_v6.pdf.

2. Briko NI, Zueva LP, Ljubimova AV, Svetlichnaja YuS, Brusina EB, Botvinkin AD, i dr. Profilaktika zanosa i rasprostranenija COVID-19 $\checkmark$ medicinskih organizacijah. Vremennye metodicheskie rekomendacii. 2020; 46 s. Dostupno po ssylke: https://bashgmu. ru/upload/\%D0\%92\%D1\%80\%D0\%B5\%D0\%BC\%D0\%B5\%D0 \%BD\%D0\%BD\%D1\%8B\%D0\%B5_\%D0\%BC\%D0\%B5\%D1\% 82\%D0\%BE\%D0\%B4\%D0\%B8\%D1\%87\%D0\%B5\%D1\%81\% D0\%BA\%D0\%B8\%D0\%B5_\%D1\%80\%D0\%B5\%D0\%BA\%D0 \%BE\%D0\%BC\%D0\%B5\%D0\%BD\%D0\%B4\%D0\%B0\%D1\%86 \%D0\%B8\%D0\%B8_\%C2\%AB\%D0\%9F\%D0\%A0\%D0\%9E\%D 0\%A4\%D0\%98\%D0\%9B\%D0\%90\%D0\%9A\%D0\%A2\%D0\%98 \%D0\%9A\%D0\%90_\%D0\%97\%D0\%90\%D0\%9D\%D0\%9E\%D0 \%A1\%D0\%90_\%D0\%98\%C2\%A0_pdf.pdf.

3. Coccolini F, Perrone G, Chiarugi M, Di Marzo F, Luca Ansaloni, Scandroglio I, et al. Surgery in COVID-19 Patients: Operational Directives. World Journal of Emergency Surgery. 2020; 15 (1): 25. DOl: 10.1186/s13017-020-00307-2.

4. Pryor A. Sages and eaes recommendations regarding surgical response to COVID-19 crisis. 2020 March 29. Available from: https://www.sages.org/recommendations-surgical-responsecovid-19/.

\section{Литература}

1. Профилактика, диагностика и лечение новой коронавирусной инфекции (COVID-19). Временные методические рекомендации. Версия 6 (28.04.2020). Доступно по ссылке: https://static-1. rosminzdrav.ru/system/attachments/attaches/000/050/116/ original/28042020\%D0\%9CR COVID-19 v6.pdf.

2. Брико Н. И., Зуева Л. П., Любимова А. В., Светличная Ю. С., Брусина Е. Б., Ботвинкин А. Д., и др. Профилактика заноса и распространения COVID-19 в медицинских организациях. Временные методические рекомендации. 2020; 46 с. Доступно по ссылке: https://bashgmu.ru/upload/\%D0\%92\%D 1\%80\%D0\%B5\%D0\%BC\%D0\%B5\%D0\%BD\%D0\%BD\%D1\%8
5. Zheng $\mathrm{MH}$, Boni L, Fingerhut A. Minimally invasive surgery and the novel coronavirus outbreak: lessons learned from Italy. Annals of Surgery. 2020.

6. Alp E, Bijl D, Bleichrodt RP, Hansson B, Voss A. Surgical smoke and infection control. Journal of Hospital Infection. 2006; 62 (1): $1-5$.

7. Repici A, Maselli R, Colombo M, Gabbiadini R, Spadaccin M, Anderloni A, et al. Coronavirus (COVID-19) outbreak: what the department of endoscopy should know. Gastrointestinal Endoscopy. 2020 Mar 13. DOI: 10.1016/j.gie.2020.03.019.

8. Wax RS, Christian MD. Practical recommendations for critical care and anesthesiology teams caring for novel coronavirus (2019-nCoV) patients. Canadian Journal of Anaesthesia. 2020; 67 (5): 568-76.

9. De SB, Chouillard E, Saverio S Di, Pagani L, Sartelli M, Biffl WL, et al. Emergency Surgery During the COVID-19 Pandemic: What You Need to Know for Practice. Annals of Royal College of Surgeons of England. 2020; 102 (5): 323-32. DOI: 10.1308/ rcsann.2020.0097.

10. Zizzo M, Bollino R, Annessi V. Pre- And Post-Operative Screening in Limited-Term Elective Cancer Surgery Patients During the COVID-19 Pandemic. Journal of Visceral Surgery. 2020; 157 (3): 69-70. DOI: 10.1016/j.jviscsurg.2020.04.015.

11. Diaz A, Sarac BA, Schoenbrunner AR, Janis JE, PawlikTM. Elective Surgery in the Time of COVID-19. American Journal of Surgery. 2020; 219 (6): 900-2. DOI: 10.1016/j.amjsurg.2020.04.014.

B\%D0\%B5_\%D0\%BC\%D0\%B5\%D1\%82\%D0\%BE\%D0\%B4\% D0\%B8\%D1\%87\%D0\%B5\%D1\%81\%D0\%BA\%D0\%B8\%D0\% B5_\%D1\%80\%D0\%B5\%D0\%BA\%D0\%BE\%D0\%BC\%D0\%B5 \%D0\%BD\%D0\%B4\%D0\%B0\%D1\%86\%D0\%B8\%D0\%B8_\%C 2\%AB\%D0\%9F\%D0\%A0\%D0\%9E\%D0\%A4\%D0\%98\%D0\%9B \%D0\%90\%D0\%9A\%D0\%A2\%D0\%98\%D0\%9A\%D0\%90_\%D0 \%97\%D0\%90\%D0\%9D\%D0\%9E\%D0\%A1\%D0\%90_\%D0\%98 \%C2\%A0_pdf.pdf.

3. Coccolini F, Perrone G, Chiarugi M, Di Marzo F, Luca Ansaloni, Scandroglio I, et al. Surgery in COVID-19 Patients: Operational Directives. World Journal of Emergency Surgery. 2020; 15 (1): 25 
DOI: 10.1186/s13017-020-00307-2.

4. Pryor A. Sages and eaes recommendations regarding surgical response to COVID-19 crisis. 2020 March 29. Available from: https://www.sages.org/recommendations-surgical-responsecovid-19/.

5. Zheng MH, Boni L, Fingerhut A. Minimally invasive surgery and the novel coronavirus outbreak: lessons learned from Italy. Annals of Surgery. 2020.

6. Alp E, Bijl D, Bleichrodt RP, Hansson B, Voss A. Surgical smoke and infection control. Journal of Hospital Infection. 2006; 62 (1): 1-5.

7. Repici A, Maselli R, Colombo M, Gabbiadini R, Spadaccini $\mathrm{M}$, Anderloni A, et al. Coronavirus (COVID-19) outbreak: what the department of endoscopy should know. Gastrointestinal Endoscopy. 2020 Mar 13. DOI: 10.1016/j.gie.2020.03.019.

8. Wax RS, Christian MD. Practical recommendations for critical care and anesthesiology teams caring for novel coronavirus (2019-nCoV) patients. Canadian Journal of Anaesthesia. 2020; 67 (5): 568-76.

9. De SB, Chouillard E, Saverio S Di, Pagani L, Sartelli M, Biffl WL, et al. Emergency Surgery During the COVID-19 Pandemic: What You Need to Know for Practice. Annals of Royal College of Surgeons of England. 2020; 102 (5): 323-32. DOI: 10.1308/ rcsann.2020.0097.

10. Zizzo M, Bollino R, Annessi V. Pre- And Post-Operative Screening in Limited-Term Elective Cancer Surgery Patients During the COVID-19 Pandemic. Journal of Visceral Surgery. 2020; 157 (3): 69-70. DOI: 10.1016/j.jviscsurg.2020.04.015.

11. Diaz A, Sarac BA, Schoenbrunner AR, Janis JE, Pawlik TM. Elective Surgery in the Time of COVID-19. American Journal of Surgery. 2020; 219 (6): 900-2. DOI: 10.1016/j.amjsurg.2020.04.014. 